\title{
Significance of Biogenic Amines in Foods and Their Reduction Methods
}

\author{
Songül Şahin Ercan, Hüseyin Bozkurt and Çiğdem Soysal \\ Department of Food Engineering, Faculty of Engineering, Gaziantep University, Gaziantep 27310, Turkey
}

Received: May 30, 2013 / Published: August 20, 2013.

\begin{abstract}
The term "biogenic amines" defines decarboxylation products such as histamine, putrescine, serotonin, tyramine, phenylethylamine, tryptamine and also aliphatic polyamines. They can be detected in both raw and processed foods. In the recent years, there is a great interest in biogenic amines as they are associated with quality, safety and freshness of some foods, particularly fermented foods. The presence of biogenic amines in foods can also be used as an indicator of hygienic quality. Biogenic amines also cause health hazards due to their toxic effects especially in sensitive individuals. It is therefore important to control and reduce the biogenic amines. The reduction can be brought about by the use of high pressure, irradiation, packaging, additives, starter cultures and by reduction of decarboxylase activity and temperature. This review summarizes the significance, function, occurrence and formation of biogenic amines in different foods and their reduction by different methods.
\end{abstract}

Key words: Biogenic amines, reduction, quality index, health effects.

\section{Introduction}

Biogenic amines are low molecular weight, organic bases and biologically active, nitrogenous compounds. Biogenic amines are synthesized during the cellular metabolic activities in microorganisms, plants and animals. They are also produced in foods, mainly by decarboxylation of amino acids [1]. Amines are classified into three categories according to their chemical structure: aromatic amines (histamine, tyramine, serotonin, $\beta$-phenylalanine and tryptamine), aliphatic diamines (putrescine and cadaverine), and aliphatic polyamines (agmatine, spermidine and spermine). They are present almost in every food in daily diet but their amounts are high in many processed foods such as: cheese, sauerkraut, sausage, beer, wine, fish, soy sauces, meat and chocolate etc. [2]. In this review, significance of biogenic amines, their formation, occurrence in food and their reduction methods are discussed.

Corresponding author: Hüseyin Bozkurt, professor, research fields: meat and meat products, food safety. E-mail: hbozkurt@gantep.edu.tr.

\section{Significance and Formation of Biogenic Amines}

Histamine, putrescine, cadaverine, tyramine, tryptamine, $\beta$-phenyl ethylamine, spermine and spermidine are the most important and common biogenic amines found in foodstuffs [3]. Importance of biogenic amines in foods is mainly due to two reasons: firstly, the intake of foods containing high content of biogenic amines causes health hazard through the direct, toxic effect of these compounds and their interaction with some medicaments [4]; secondly, they may have a role as indicators of quality and/or acceptability in some foods [5].

\subsection{Formation of Biogenic Amines}

Biogenic amines are usually produced by decarboxylation of free amino acids or by amination and transamination of aldehydes and ketones. Amino acid decarboxylation occurs by removal of the $\alpha$-carboxyl group from a precursor amino acid and leads to production of biogenic amines (Fig. 1). Biogenic amines are formed by enzymes in raw material or by microbial 
<smiles>O=C1CC[C@H](Cc2cnc[nH]2)[C@H]1O</smiles>

Histidine

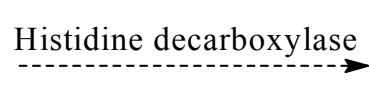

(a)<smiles>[CH][CH]c1cnc[nH]1</smiles>

Histamine<smiles>N[C@H](Cc1ccc(O)cc1)C(=O)O</smiles>

Tyrosine<smiles>N=C(N)NCCC[C@H](N)C(=O)O</smiles>

Arginine

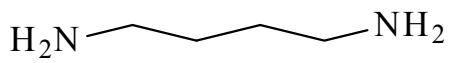

Putrescine
Tyrosine decarbxylase<smiles>NCCc1ccc(O)cc1</smiles>

Tyramine

(b)

Arginine decarboxylase<smiles>N=C(N)NCCCCN</smiles>

Agmatine iminohydrolase

$\mathrm{N}$-carbamoylputrescine aminohydrolase

(c)<smiles>NCCCCNC(N)=O</smiles>

Fig. 1 Formation of histamine (a), putrescine (b) and tyramine (c).

decarboxylation of amino acids during aging and storage in food [6,7]. Free biogenic amines give a typical taste for mature foods and are precursors of certain aromatic compounds. Also, production of amines has been associated with the protective mechanisms of microorganisms against an acidic environment. For example, lactic acid bacteria produce biogenic amines to survive during fermentation of foods such as in cheese, sausage and fermented vegetables [8].

The names of many biogenic amines correspond to the names of their originating amino acids. For example, histidine is decarboxylated to produce histamine, tryptophan to tryptamine, tyrosine is decarboxylated to produce tyramine [9]. In plants and some microorganisms, alternative pathway exists to produce putrescine from arginine via agmatine. Lysine is decarboxylated by lysine decarboxylase to produce cadaverine although it can also be formed by ornithine decarboxylase if the content of ornithine is low but that of lysine is high [10].

Biogenic amines can be found as a consequence of microbial activity in foods such as wine, fermented meat, fish products, cheeses and fermented vegetables. It is known that amino acid decarboxylases are enzymes produced in many microorganisms found in 
microbiota of food products or contaminated before, during, or after food processing. The decarboxylase producing species are the genera of the Bacillus, Clostridium, Pseudomonas and Photobacterium. On the other hand, they are also present in genera of the family Enterobacteriaceae such as Citrobacter, Klebsiella, Escherichia, Proteus, Salmonella and Shigella and Micrococcaceae such as Staphylococcus, Micrococcus and Kocuria. Furthermore, many lactic acid bacteria belonging to the genera Lactobacillus, Enterococcus, Carnobacterium, Pediococcus, Lactococcus and Leuconostoc are able to decarboxylate one or more amino acids $[10,11]$.

Biogenic amine formation by the microbial decarboxylation of amino acids is dependent on many factors such as: the specific bacterial strains present, the level of decarboxylase activity and the availability of the amino acid substrate [12].

\subsection{Role of Biogenic Amines}

Biogenic amines play important role in human body such as: regulation of body and stomach $\mathrm{pH}$, gastric acid secretion, the immune response and cell growth and differentiation. At the same time, amines are important for the growth, renovation and metabolism of every organ in body and essential for maintaining the high metabolic activity of the normal functioning and immunological system of gut. Further, when polyamines are taken up preferentially by tissues with high demands, they could be useful for post-operation patients or during wound healing and for growth and development of the neonata's digestive system [13, 14].

Despite these roles, the consumption of foods with high content of biogenic amines can cause adverse reactions such as nausea, headaches, cardiac palpitation, hot flushes, oral burning, gastric intestinal problems, renal intoxication, rashes and changes in blood pressure [15]. In the human body, there is a detoxification system that degrades biogenic amines to physiologically less active form. Diamine oxidase and monoamine oxidase are two groups of enzymes that have role in this detoxification. However, intake of high content of biogenic amines causes deactivation of detoxification system. In addition, some drugs reduce the activity of monoamine oxidases. In that case, this enzyme can not act leading to absorption of biogenic amines by human body and show toxic effects [16].

Different biogenic amines can cause different side effects such as: excess tyramine intake could cause hypertension meanwhile serotonin is a vasoconstrictor. There are some toxic effects of biogenic amines such as histamine poisoning (scombroid poisoning), a worldwide problem that occurs after the consumption of food containing biogenic amines particularly histamine at contents higher than $500 \mathrm{mg} / \mathrm{kg}$, whereas, allowable level in fish is maximum $50 \mathrm{mg} / \mathrm{kg}$ [17]. Histamine poisoning is an allergen-type reaction and is characterized by difficulty in breathing, itching, rash, vomiting, fever and hypertension. These symptoms can be seen in people having deficient natural mechanisms for detoxifying biogenic amines due to genetic defects or due to the intake of antidepressant medicines such as monoamine oxidase inhibitors [18].

Histamine intake of 8-40 mg, 40-100 mg and higher than $100 \mathrm{mg}$ may cause slight, intermediate and intensive poisoning, respectively [19]. Nout [20] pointed out that maximum histamine content is $50-100 \mathrm{mg} / \mathrm{kg}$ for sausages. The allowable maximum level of tyramine in foods is $100-800 \mathrm{mg} / \mathrm{kg}$ and $1,080 \mathrm{mg} / \mathrm{kg}$ of tyramine is toxic for humans [3]. Putrescine, spermine, spermidine and cadaverine do not have adverse health effects but they may react with nitrite to form carcinogenic nitrosamines and are also proposed as indicators of spoilage [21, 22]. Naila et al. [23] reported oral toxicity levels for putrescine $(2,000 \mathrm{mg} / \mathrm{kg})$, cadaverine $(2,000 \mathrm{mg} / \mathrm{kg})$, tryptamine $(2,000 \mathrm{mg} / \mathrm{kg})$, spermidine $(600 \mathrm{mg} / \mathrm{kg})$ and spermine $(600 \mathrm{mg} / \mathrm{kg})$.

Biogenic amines are considered as precursors of carcinogenic amines such as $\mathrm{N}$-nitrosamines and they are also indicators of food quality. In foods, nitrosamines are produced from nitrites and secondary amines. The following are a few explanations given for 
the formation of nitrosamines: (1) nitrite and its derivatives may react with some biogenic amines to produce volatile N-nitrosamine; (2) nitrite can be converted into nitrosating agents that may easily react with secondary amines to produce carcinogenic $\mathrm{N}$-nitrosamines; (3) some biogenic amines may react with nitrosating agents to produce N-nitrosamines; (4) primary amines such as putrescine and cadaverine have been suggested to cyclize during heating to secondary amines such as pyrolidine and piperidine which react with nitrite to form carcinogenic nitrosamines [24, 25]. Formation of nitrosamines in meat and meat products is a problem especially in terms of toxicological point of view.

\subsection{Quality Index}

Presence of biogenic amines in foods can be used as quality index. They are expressed as chemical indicators of the hygienic conditions of raw material. Their accumulation is related with the activity of contaminant bacteria during the manufacturing practices [26]. Generally, presence of biogenic amines in non-fermented foods is explained as inadequate or prolonged storage. However, presence of these in meat and meat products is used as a quality index for unwanted microbial activity.

Some authors have proposed chemical index $(C H I)$ consisting of putrescine (PUT), cadaverine $(C A D)$, histamine $(H A)$, spermidine $(S P D)$ and spermine $(S M)$ concentration. Such a chemical index was expressed [27] to evaluate the quality of canned tuna and decomposition of rock fish and salmon fillets:

$$
C H I=\frac{(P U T+C A D+H A)}{(1+S P D+S M)}
$$

For canned tuna, $C H I$ between 0 and 1 indicate good (class 1) product while for borderline (class 2) canned tuna, the chemical index is between 1 and 10 .

On the other hand, there is an amine index $(A I)$ used to evaluate spoilage of plaice and whiting by use of PUT, CAD, HA, tyramine (TYR), tryptamine (TRP), methylamine $(M A), S P D$ and $S M$ :
$A I=\frac{(P U T+C A D+H A)}{(P U T+C A D+H A+T Y R+T R P+M A+S P D+S M)} \times 100$

According to this index, good quality whiting has an $A I$ below 25, for plaice, it is below 15 . However, whiting and plaice become inedible when the $A I$ exceeded 66 and 55, respectively [24].

Hernandez-Jover et al. [22] used same index and explained that $A I<5 \mathrm{mg} / \mathrm{kg}$ for good quality fresh meat; between $5 \mathrm{mg} / \mathrm{kg}$ and $20 \mathrm{mg} / \mathrm{kg}$ for acceptable meat but with initial spoilage signs; between $20 \mathrm{mg} / \mathrm{kg}$ and 50 $\mathrm{mg} / \mathrm{kg}$ for low meat quality; finally $A I>50 \mathrm{mg} / \mathrm{kg}$ for spoiled meat. Biogenic amine indexes are generally suggested for fish and fish products and meat and meat products. There is no information about the use of biogenic amine index for fermented food products. This could be due to the highly varied biogenic amine content in fermented products than in fresh meat and cooked meat products. There are many factors affecting these variations such as: microbiota of raw material, manufacturing practices, processing stages, type of starter cultures and species. Hence, specific biogenic amine index has been suggested only for fresh or processed meat and meat products and not for fermented foods [28].

Generally, putrescine and cadaverine contents are used as quality index of meat and meat products because their amounts increase due to the spoilage. It was reported that $500 \mathrm{mg} / \mathrm{kg}$ of total biogenic amine content is the limit for Bologna sausage, minced beef and pork [29].

\section{Occurrence of Biogenic Amines in Food}

Biogenic amines are present in many different foods although their contents vary widely between and even within food types. In addition, they may not be equally distributed within foods [15]. Although existing as endogenous components of fresh foods such as fruits and vegetables, biogenic amines can accumulate as the result of uncontrolled microbial enzymatic activity [30]. Cheese, meat and meat products and beverages are example of foods that contain high levels of biogenic 
amines (Table 1). There are many factors influencing biogenic amine formation. These are storage conditions (temperature and humidity), $\mathrm{pH}$ of the product, food composition (especially protein), additives, species, heat application, manufacturing practices, presence of decarboxylase producing microorganisms, raw material quality and the availability of free amino acids $[9,31]$.

\subsection{Fish and Fish Products}

Fish and fish products contain high amounts of protein. Fish must be kept under proper conditions from harvest stage to consuming point, otherwise, it can be hazardous to human health. Many biogenic amines may be present in fish and fish products such as histamine, cadaverine and putrescine. They have been used for determination of fish safety and quality. Although there are many reports about biogenic amine content of fish and fish products, most of them are about histamine and scombroid food poisoning [24]. Blood and organs of scombroid type fish contain considerably higher amount of free histidine. On the other side, deep red coloured muscle of this type of fish contains three times higher amount of proteolytic activity than white coloured muscle. If histamine is produced in fish muscle, it can not be reduced by cooking or frying. Histamine formation of scombroid type of fish can be stopped by retort, but amount of histamine present in fish can not be reduced [32].

Despite a widely reported association between histamine and scombroid food, poisoning histamine alone appears to be insufficient to cause food toxicity. Biogenic amines like putrescine and cadaverine are important for fish and fish products. When microbial decomposition begins in fish, putrescine and cadaverine content increase continuously. Existence of putrescine is used as a spoilage indicator for fish quality and cadaverine is used as index for microbial spoilage in a wide range of fish, especially nonpelagic fish. On the other hand, putrescine has not been reported to be involved in scombroid poisoning, but the presence of putrescine and cadaverine together has been reported to induce histamine allergy [24].

\subsection{Cheese}

Cheese is on the second place after fish in terms of biogenic amine content. Cheese contains proteins, enzymes, cofactors, water, salt and bacteria, therefore represents an ideal environment for microbial growth so biogenic amine formation [10]. Proteolysis is the

Table 1 Biogenic amine content of some foods.

\begin{tabular}{|c|c|c|c|c|c|}
\hline \multirow{2}{*}{ Food } & Histamine & Tyramine & Cadaverine & Putrescine & \multirow{2}{*}{-References } \\
\hline & \multicolumn{4}{|c|}{$(\mathrm{mg} / \mathrm{kg})$} & \\
\hline \multicolumn{6}{|l|}{ Fish and fish products } \\
\hline Tuna (canned) & 20,000 & & 4,440 & 2,000 & [33] \\
\hline Fermented fish paste & 640.0 & 376.0 & 35.0 & & [33] \\
\hline Fresh fish & 209 & 61.8 & & & {$[34]$} \\
\hline \multicolumn{6}{|l|}{ Dairy products } \\
\hline Milk & & & & 0.013 & {$[35]$} \\
\hline Terrincho cheese & 15.6 & 15.6 & 349.7 & 217.8 & [36] \\
\hline \multicolumn{6}{|l|}{ Meat products } \\
\hline Salchichon & 7.3 & 280.5 & 11.7 & 5.5 & [33] \\
\hline Dry cured ham & 114 & 104 & 64 & 97 & [37] \\
\hline Dry fermented sausage & 286.0 & $1,500.0$ & & 396.0 & [33] \\
\hline \multicolumn{6}{|l|}{ Fermented drinks } \\
\hline Beer & 3.0 & 3.6 & 1.3 & 7.6 & {$[38]$} \\
\hline Cider & 6.9 & 4.1 & & 12.3 & [39] \\
\hline Wine & 3.3 & & & 3.3 & [33] \\
\hline Porto wine & 2.3 & 2.6 & 0.1 & 11.9 & {$[16]$} \\
\hline
\end{tabular}


most important phenomenon in cheese during the maturation period. In this period, casein is ruptured by proteolytic enzymes and this causes increase in free amino acids. Some of these free amino acids can be subjected to decarboxylation reactions which are catalyzed by specific bacterial decarboxylase activity and resulting formation of amines [40]. Biogenic amine accumulation in cheese can be influenced by the microbiological quality of raw milk, the sanitization procedures adopted, the use of starter cultures and the conditions and time of the ripening process [36]. Besides this, amount and type of microorganisms, interaction between microorganisms, level of proteolysis, maturation and storage temperature, maturation period and salt concentration of brine are some other important factors that affect biogenic amine content of cheese. The most abounded biogenic amines that present in cheeses are histamine, tyramine, cadaverine, putrescine, tryptamine and phenyl ethylamine. Also presence of these amines in cheese indicates a failure in hygienic quality of milk used for cheese products or during the cheese making [41].

\subsection{Meat and Meat Products}

Meat and meat products are important components of daily diet and they contain different types of biogenic amines in varying contents. The most common biogenic amines in meat and meat products are tyramine, cadaverine, putrescine and also histamine. Meat is the natural source of the substrate (free amino acids) from which biogenic amines are produced. It is also the largest component of the matrix in which the decarboxylation reactions take place and therefore basic in determining essential factors in enzymatic activity: $\mathrm{pH}$, ionic strength, substrate concentration, inhibitors and their mobility, etc.. Thereby, any conditions that change its nature and characteristics will influence the formation of biogenic amines in one way or another [28].

There are several reports about biogenic amine content of meat and meat products and most of them focus on fermented sausages. Amine content and profiles may vary depending on several extrinsic and intrinsic factors during the manufacturing process such as ripening conditions, formulation, $\mathrm{pH}$, temperature, additives, diameter of sausages, salt/water ratio, proteolytic activity, as well as microflora development and its decarboxylase activity [42]. Fermented sausages contain suitable environment for production of biogenic amines (presence of free amino acids, presence of microorganisms with decarboxylase activities and conditions favorable for the growth of microorganisms) [43].

One of the most important factor influencing biogenic amine formations in dry fermented sausages is the starter culture [44, 45]. The microorganisms responsible for decarboxylation reactions may be introduced as starter culture in sausages or may constitute part of the natural population of the food. Enterobacteriaceae can be involved in the production of putrescine, histamine and cadaverine [46] and Pseudomonas in the production of putrescine [47]. Regarding lactic acid bacteria, all strains of Carnobacterium found in meat products produced high amounts of tyramine and some strains of Lactobacillus curvatus and Lactobacillus plantarum used as starter cultures gave rise to tyramine production [48].

On the other hand, microorganisms that produce decarboxylase enzymes have an important role in biogenic amine formation in meat and meat products. In general, Enterobacteriaceae, Pseudomonadaceae, Micrococcaceae and lactic acid bacteria appear to be the main producers of decarboxylase in fermented products [49]. During storage period, production of biogenic amines can be expected to continue due to the presence of active microbiota in these products $[28,50]$.

The different types of processing and storage conditions that are applied to meat products can influence the formation of biogenic amines. Fermentation processes usually between $7{ }^{\circ} \mathrm{C}$ and 28 ${ }^{\circ} \mathrm{C}$ generally increase the formation of biogenic amines. Fermented products contain large quantities of 
microorganisms. These microorganisms can cause proteolysis to produce high amounts of free amino acids which are substrate for decarboxylase enzymes to produce biogenic amines. However, these conditions are affected by several factors such as the temperature of the medium, the microorganisms present and the presence of additives [21].

It was reported that increase in salt concentration significantly decreased biogenic amine content in dry sausages [51]. Also they observed higher proteolytic activity when intermediate concentration of salt was used.

\subsection{Alcoholic Beverages}

Alcoholic beverages like other fermented foods may contain biogenic amines as a result of decarboxylation of certain amino acids by the microorganisms used in their production [52]. Biogenic amine contents of alcoholic beverages such as boza (a traditional cereal-based fermented Turkish beverage), beer and cider (an alcoholic beverage made from apple juice) have been studied [53-56]. However, wine is the most commonly studied alcoholic beverage in this area. In wine, several amino acids can be decarboxylated so that histamine, tyramine, putrescine, cadaverine and phenyl ethylamine are produced but histamine, tyramine and putrescine are the main biogenic amine observed in wine [16, 57].

The presence of biogenic amines in wines has been studied extensively since 1980 and particularly over the last 10 years as a consequence of the increasing attention to consumer protection. In order to eliminate biogenic amines in wine, it is necessary to identify the source of these compounds [58]. Biogenic amines can be already present in "must" or formed by the yeast during alcoholic fermentation. The other alternative for origin of biogenic amines in wine is the action of bacteria involved in malolactic fermentation $[59,60]$. Some amines are normally present in grapes depending on the soil type and composition, fertilization of soil, climatic conditions during growth, degree of maturation, elaboration method used for the wine extraction, autolysis and growth of lactic acid bacteria, residual microbial population, clarification process, enological treatment of the wine as well as the yeast strain used in the fermentation [61]. In several studies, biogenic amines have been suggested as indicators of a lack of hygiene during the winemaking process or associated (in the case of putrescine and cadaverine) with poor sanitary conditions of grapes [58].

Fermentation conditions of wine are also important for the biogenic amine production. These are: temperature, $\mathrm{pH}$, access to oxygen, sodium chloride content, "must" treatment, length of fermentation, presence of pulp and skin, alcohol content, concentration of sulphurdioxide and added nutrients, quantity and type of finings, and clarification agents used [16].

Putrescine, cadaverine, histamine and isoamylamines are reported as the most abundant amines in the wine samples analyzed. The relative concentrations of biogenic amines expressed in $\mathrm{mg}^{-1}$ are reported as follows: putrescine $>$ histamine $>$ isoamylamine $>$ ethylamine $>$ methylamine $>$ cadaverine $=$ tyramine $=$ agmatine $=$ tryptamine Agmatine $(0.18 \mathrm{mg} / \mathrm{L})$ was detected within the analyzed 32 samples of commercially available Greek wines [62]. In another study, agmatine was only found in some red wine samples with a maximum value of $0.63 \mathrm{mg} / \mathrm{L}$. It is considered as an intermediate product of the metabolism of arginine to putrescine. It has also been related to food spoilage [63]. However, Proestos et al. [62] reported that the relationship between agmatine and spoilage can not be applied to wine on the basis of their results.

The types and levels of amines in beers are affected mainly by raw materials, brewing techniques, and microbial contamination during brewing [64]. Malt is a source of agmatine, putrescine, spermidine and spermine, while tyramine histamine and cadaverine have been formed during fermentation by contaminating lactic acid bacteria [38]. Tyramine, 
putrescine, spermine, spermidine and agmatine have also been detected in barley. Relatively high levels of tyramine, 2-phenylethylamine, putrescine, spermine, spermidine and agmatine have been detected in hops, however, its contribution to amine levels in beer is not significant since the amount used is very small. The use of adjunct cereals such as rice is useful in reducing biogenic amine levels in worts and beers [64].

Beer samples with four different fermentation types (low fermentation, top fermentation, top fermentation followed by a second fermentation into bottle and spontaneous fermentation (SF)) were analysed [8]. Spermine and spermidine were not detected in the analysed samples. By contrast, putrescine and agmatine presented a fairly constant content in all samples. The above study considered that both amines are natural components brought to the beverage by raw material as reported earlier $[65,66]$.

\section{Reduction Methods of Biogenic Amines}

\subsection{High Pressure Processing}

High pressure processing is one of the emerging technologies which can be applied at refrigeration, ambient or moderately high temperatures to inactivate pathogenic and spoilage microorganisms, and enzymes in foods with fewer changes in texture, colour and flavor compared to conventional technologies. It has aroused more interest in recent years because it addresses consumer demands for safe better quality products with fewer additives, less processing and prolonged shelf life [18]. There are many foods that are treated by high pressure such as cheese [67], sausage [42, 68, 69], carrot [70] and sauerkraut [71]. High pressure treated food materials have been reported to maintain their original flavour and characteristic properties with extended shelf life [72].

High pressure is a useful method for cell disruption and alters permeability of cell membrane which causes reduction of amino acid uptake due to membrane protein denaturation [73]. It is followed by leakages on the cellular membrane resulting in a greater degree of death and injury. In a fermentation process when high pressure is applied to raw material or the end products, a reduction in the number of bacteria is observed which inhibit biogenic amine formation. Lanciotti et al. [73] observed that if milk is subjected to a homogenization treatment by high pressure before cheese making, both microbial load and biogenic amine content of cheeses during ripening are significantly influenced. A drastic reduction is observed in biogenic amine content of cheese treated with high pressure compared to the cheese produced by the same milk without any treatment. However, level of pressure applied is a significant factor to reduce biogenic amine formation. Report of Rodriguez et al. [67] support this statement that a low pressure treatment (50 MPa for $72 \mathrm{~h}$ ) increased biogenic amine content while a high pressure treatment (400 MPa for $5 \mathrm{~min}+50 \mathrm{MPa}$ for $72 \mathrm{~h}$ ) showed a slight decrease. Effects of high pressure on fermented sausages have also been studied and it has been observed that treating fermented sausage with high pressure $(350 \mathrm{MPa} / 15 \mathrm{~min})$ reduced lactic acid bacteria and thereby decreased cadaverine, putrescine and tyramine levels during 160 days chilled storage compared to sausage not treated with high pressure [68]. Reduction of lactic acid bacteria together with biogenic amines may cause some problems in fermented foods. Therefore, to control biogenic amine formation in fermented foods, high pressure application could be feasible before starter culture addition.

\subsection{Irradiation}

Food irradiation has been used for inhibition of sprouting, destruction of food borne insects and parasites, delay of physiological ripening, extension of shelf life and improvement of food quality [74]. Food irradiation is considered as an alternative method to thermal processes because of the severe detrimental effects of thermal processing upon texture and flavor. Furthermore, irradiation technology is applied to reduce substances such as carcinogenic $\mathrm{N}$-nitrosamines and nitrite in meat products, allergenicity in foods and 
biogenic amines in foods [75]. Significant progress has recently been made by use of $\gamma$-irradiation to reduce the levels of biogenic amines in foods [76, 77].

Gamma-irradiation has positive impact on the reduction of viable numbers of microorganisms and viruses, furthermore, it appears to reduce biogenic amines and nitrosamine formation in protein rich foods [78]. Gamma-irradiation has been reported to be effective in reducing the content of biogenic amines in both aqueous solutions and fermented soybean paste $[75,76]$. It also has been reported to be effective in reducing the major biogenic amines in ground beef and pork following inoculation with three different microorganisms [77].

Although food irradiation is an effective method to reduce biogenic amine formation, public acceptance is low. Most researches report that people have insufficient information about food irradiation. Irradiated food products are generally considered "carcinogenic" and so acceptance of irradiated foods is low [79]. There are many food materials that are irradiated to inactivate biogenic amines. These are: pepperoni, low salted fermented soybean paste, beef and pork, vacuum packed chub mackerel (Scomber japonicus), distilled water and blue cheese [76, 77, 80-82]. Min et al. [77] studied ground pork and beef inoculated with Alcaligenes faecalis, Bacillus cereus and Enterobacter cloacae which were treated with gamma-irradiation dose of $2 \mathrm{kGy}$. They found that total amount of biogenic amines (histamine, tyramine, spermidine, beta-phenyl ethylamine, tryptamine, cadaverine and putrescine) formed during $24 \mathrm{~h}$ storage at $4{ }^{\circ} \mathrm{C}$ was reduced by the treatment. Also it was found that levels of tyramine, spermidine, spermine and putrescine were effectively reduced in pepperoni by gamma-irradiation (5, 10 and $20 \mathrm{kGy}$ ) [75]. Kim et al. [81] observed that gamma-irradiation at 5, 10 or 15 kGy reduced putrescine, cadaverine, agmatine, histamine, tryptamine, spermine and spermidine during fermentation of low salt fermented soy paste [81]. The formation of biogenic amines after irradiation and vacuum packing reduced in chub mackerel (Scomber japonicus) in chilled storage [82].

\subsection{Application of Additives}

Spices and herbs are additives which are generally used in foods for enhancing the flavor or colour attributes. These materials also have antimicrobial and antioxidant activities [44]. Many reports show that spices and herbs reduce biogenic amine production (Table 2). Curcumin (turmeric), capsaicin (red pepper), and piperine (black pepper) are naturally occurring specific inhibitory substances that inhibit biogenic amine formation [83]. Yücel and Üren [84] reported that components in spices such as thymol inhibit biogenic amine formation. It was observed that citric acid use in pickled cabbage fermentation produced a slight decrease in biogenic amines [85]. Sodium nitrite addition in dry sausage fermentation was studied by Bozkurt and Erkmen [86] and they found that biogenic amine production was decreased with sodium nitrite addition. Use of nitrite in sucuk production has been found to affect the formation of biogenic amines except for spermidine and spermine [45]. Effect of sodium sulphite on biogenic amine accumulation during the ripening of slightly fermented sausages has been studied. The study reported stimulation of tyramine production in the presence of sulphite, whereas, cadaverine formation was drastically inhibited [87]. Reduction of cadaverine formation has been observed when sugar was added to slow fermented sausages [88].

\subsection{Reduction of Decarboxylase Activity}

Biogenic amines are formed by the enzymatic decarboxylation of free amino acids (Fig. 1). Necessary conditions for the production of biogenic amines are: presence of free amino acids and decarboxylase enzymes and appropriate conditions for decarboxylation. Free amino acids are produced by the action of microbial proteolytic enzymes which convert proteins to amino acids and also these amino acids are 
Table 2 Reduction of biogenic amines by additives.

\begin{tabular}{|c|c|c|}
\hline Food type & Additives & Reduction in biogenic amines \\
\hline \multirow{7}{*}{ Fermented sausage } & & Putrescine value: \\
\hline & Sesama oil, BHT, & Thymbra spicata oil $<$ Sesama oil $<$ BHT $<$ control \\
\hline & Thymbra spicata oil & Lowest histamine and tyramine concentrations were obtained in ${ }^{[89]}$ \\
\hline & & Thymbra spicata and sesama oil added recipes \\
\hline & $\begin{array}{l}\text { BHT, H. Sabdariffa, } \\
\text { U. dioica, nitrite/nitrate }\end{array}$ & $\begin{array}{l}\text { U. dioica was more effective in decreasing histamine and } \\
\text { putrescine }\end{array}$ \\
\hline & & Antioxidants reduced putrescine formation in the following order: \\
\hline & $\begin{array}{l}\text { BHT, Thymbra spicata } \\
\text { oil, green tea extract }\end{array}$ & $\begin{array}{l}\text { Green tea extract }>\text { green tea extract-Thymbra spicata oil }> \\
\text { Thymbra spicata oil }>\text { BHT lowest tyramine concentration was } \\
\text { observed in the recipe with green tea extract }\end{array}$ \\
\hline \multirow{2}{*}{$\begin{array}{l}\text { Myeolchijeot (fermented } \\
\text { anchovies) }\end{array}$} & Garlic extract & Histamine and tyramine reduced by $20.8 \%$ and $31.2 \%$ \\
\hline & Glycine $\mathrm{NaCl}$ & $\begin{array}{l}\text { Putrescine cadaverine histamine tyramine spermidine reduced } \\
\text { between } 63 \% \text { and } 73 \% \text { compared with the control }\end{array}$ \\
\hline \multicolumn{2}{|c|}{ Slightly fermented sausage Sugars (glucose, lactose) } & Cadaverine reduction was observed \\
\hline
\end{tabular}

BHT: butylated hydroxytoluene.

converted to biogenic amines by the amino decarboxylase enzymes. Biogenic amine formation can be regulated by controlling these rate limiting decarboxylase enzymes (Fig. 1). It was reported that the proteolytic enzymes were effective in the reduction of histidine decarboxylase [93]. Effect of trypsin and chymotrypsin on the activity of histidine decarboxylase in different rat tissues has been also studied. Use of these enzymes strongly inactivated histidine decarboxylase in rats. Romantsev and Prozorovskii [94] also reported effect of trypsin on the reduction of histidine decarboxylase from Micrococcus sp. histidine decarboxylase lost $50 \%$ of its activity after the first 9 min of hydrolysis. They also studied the thermal stability of this enyzme and found that it preserves $80 \%$ activity after $5 \mathrm{~min}$ of incubation at $72{ }^{\circ} \mathrm{C}$ and at $\mathrm{pH}$ 5.55. In the literatures, there is little information about the reduction of biogenic amine formation by inhibition of decarboxylase enzymes.

\subsection{Use of Starter Cultures}

Starter cultures are pure or mixed beneficial microorganisms used in fermented food products. Application of starter cultures with amino oxidase activity is important due to the inhibiting formation of biogenic amines [10]. It was reported that rapid $\mathrm{pH}$ reduction by amine negative starter cultures can largely prevent biogenic amines accumulation in fermented products. The use of amino negative starters such as $L$. sakei or Pediococus pentosaceus could prevent the formation of biogenic amines in dry sausage [31]. Also, starter cultures able to compete with non-starter bacteria during the process especially ripening and throughout storage can further avoid excessive biogenic amines production [7]. It was reported that the natural microbiota of sucuk (Turkish dry fermented sausages) produced high levels of tyramine and putrescine (more than $250 \mathrm{mg} / \mathrm{kg}$ ), whereas, the addition of mixed starter cultures (L. sakei, $P$. pentosaceus, S. xylosus and S. carnosus) prevented the formation of putrescine but not of tyramine [95]. $S$. xylosus has been found to be effective in inhibiting biogenic amine formation in a salted and fermented anchovy [96]. Inoculation of L. plantarum in sauerkraut [97] and in Nham [98], a Thai fermented sausage effectively decreased the production of tyramine, putrescine and cadaverine. These researches show that different starter cultures show different effects. Some authors found that starter cultures were not sufficient to prevent the formation of biogenic amine in some fermented meat products. It can be related with the insufficient hygienic quality of raw meat [99].

\subsection{Degradation of Biogenic Amines}

There are some methods that can be applied to 
degrade formed biogenic amines such as use of amine oxidizing microorganism and/or enzymes like diamine oxidase and use of amine degrading microorganisms such as Lactobacillus plantarum or vineyard ecosystem fungi in wine making process. Capozzi et al. [100] analyzed 26 strains of Lactobacillus plantarum for their ability to degrade biogenic amines commonly found during wine fermentation. They selected two strains of $L$. plantarum due to their ability to degrade putrescine and tyramine. The degradation was assessed in vitro both in presence of the biogenic amines and in presence of the specific chemical precursor and of producer bacteria. The two L. plantarum biotypes were found to work synergistically. Cueva et al. [101] isolated 44 grapevine and vineyard soil fungi from four locations of Spain and evaluated for in vitro amine degradation in a micro fermentation system. All fungi were able to degrade at least two different primary amines. Species of Pencillium citrinum, Alternaria sp., Phoma sp., Ulocladium chartarum and Epicoccum nigrum were found to exhibit the highest capacity for amine degradation.

The use of bacteria with amine oxidizing activity or oxidizing enzymes has been studied by some researchers to reduce already formed biogenic amine levels in foods. Naila et al. [102] studied the amount of histamine degradation by diamine oxidase in model (buffer) and real (cooked tuna soup used in manufacture of a fish paste product, Rihaakuru) systems. They reported a technique using diamine oxidase to reduce histamine from $500 \mathrm{mg} / \mathrm{L}$ to undetectable levels $(<0.5 \mathrm{mg} / \mathrm{kg})$ in Rihaakuru. They found that histamine can be degraded at low salt levels $(12 \%)$ and $\mathrm{pH} 6.7$, but they also reported that in this condition, product sensory characteristics may vary. Dapkevicius et al. [103] also investigated the degradation of histamine by diamine oxidase in fish silage and fish slurry by using $2 \% \mathrm{NaCl}, 12 \%$ saccharose and $0.05 \%$ cysteine and found that amine oxidase was only effective in degrading histamine in the presence of cysteine. Use of diamine oxidase can be a potential method for degradation of histamine but there needs additional studies to see its effects in degrading other biogenic amines and also on food product characteristics.

\subsection{Packaging}

Modified atmosphere packing (MAP) is a form of packaging involving the removal of air from the pack and the replacement with a single gas or mixture of gases. The gaseous atmosphere changes continuously during storage because of respiration of the packed product, biochemical changes and due to the slow permeation of gases through the packaging materials. Modified atmosphere packaging of foods has gained considerable popularity as a modern method for packaging of fresh meat [104]. Combination of $\mathrm{CO}_{2}$, $\mathrm{N}_{2}$ and $\mathrm{O}_{2}$ in modified atmosphere packs is able to suppress the aerobic spoilage flora of perishable foods such as meat, fish, and related products and to sustain their visual appearance [105].

There are some reports on the successful control of biogenic amines formation through modified atmosphere packaging such as in fish, chicken, sausage, garfish and seer fish $[80,105,106]$. All these reports represent reduction of biogenic amines with MAP but effectiveness of this method depends on concentration of gases used in MAP, microbiota present and storage conditions. MAP is reported to extend the shelf life of foods with lower histamine content longer than vacuum packing [32]. Sing et al. [107] studied the effect of MAP in precooked chicken meat stored at 4 ${ }^{\circ} \mathrm{C}$ for 23 days. Samples packed under MAP had an apparent reduction in putrescine and tyramine compared with those packed under air after the storage period. It has been also reported that MAP has a strong inhibitory effect on yellow fin tuna during the storage period ( $1{ }^{\circ} \mathrm{C}$ for 28 days) [108].

\subsection{External Factor: Temperature}

Temperature is an important factor in the formation of biogenic amines. Biogenic amine formation is 
decreased at low temperatures with inhibition of microbial growth and reduction of enzyme activity [109]. It was reported that higher fermentation temperature $\left(24{ }^{\circ} \mathrm{C}\right)$ favor the growth of lactic acid bacteria which outgrew the amine-positive non-starter microorganisms. Higher temperature can favor proteolytic and decarboxylation reactions resulting in increased amine content after storage [51]. In addition, freezing is an alternative method for stabilization of the level of biogenic amine. Many reports show the efficiency of low temperature application on the reduction of biogenic amines. Yellow fin tuna stored up to 9 days at $0{ }^{\circ} \mathrm{C}$ and $22{ }^{\circ} \mathrm{C}$ showed an increase in histamine of $15 \mathrm{mg} / \mathrm{kg}$ at $0{ }^{\circ} \mathrm{C}$ and $4,500 \mathrm{mg} / \mathrm{kg}$ at 22 ${ }^{\circ} \mathrm{C}$ [110]. On the other hand, high temperature treatment is also an effective method for prevention of biogenic amine formation. High temperature treatment could kill the microorganisms responsible for histamine formation and prevent the subsequent formation of histamine. Histamine could reform after the application of heat treatment if recontamination occurs and if temperature control could not be supplied [18]. Biogenic amine content of different types of cheese showed that these compounds are common in those made from raw milk [111]. The amount of biogenic amine is generally higher in cheese made from raw milk than pasteurized milk [112].

Control of the biogenic amine is not always possible with temperature alone because some bacteria can produce biogenic amines even at temperatures below 5 ${ }^{\circ} \mathrm{C}$ [113]. Therefore, biogenic amine formation in food can be controlled by use of cold chain. However, maintaining the cold chain in foods that already contain high levels of biogenic amines will generally stabilize the levels of biogenic amines [114].

\section{Conclusions}

Biogenic amines are organic compounds present naturally or form and increase in foods after harvesting or processing. They are used as a quality indicator that shows degree of spoilage, use of non-hygienic raw material and poor manufacturing environment. These compounds are also toxic to human body and consumption of high doses of biogenic amines causes some diseases (neurological, gastro intestinal and cancer). Therefore, further research is needed to make clear toxic doses of each biogenic amine in each foodstuff and these limits have to be enforced by laws in countries which have been developing and have no regulations in this regard. Reduction of biogenic amine formation is also an important area and there are some physical and chemical methods to reduce them. Mechanism of reduction is mainly based on inhibition of bacteria. Although they seem as efficient methods for reduction of biogenic amine content of foods, their effects on quality and safety of foods should also be considered. Main goal of food production is to produce safe products with high nutritional quality.

\section{References}

[1] M. Saaid, B. Saad, N.H. Hashim, A.S.M. Ali, A.I. Saleh, Determination of biogenic amines in selected Malaysian food, Food Chem. 113 (2009) 1356-1362.

[2] S. Bodmer, C. Imark, M. Kneubhl, Biogenic amines in foods: Histamine and food processing, Inflamm. Res. 48 (1999) 296-300.

[3] A.R. Shalaby, Significance of biogenic amines to food safety and human health, Food Res. Int. 29 (1996) 675-690.

[4] S. Bardocz, Polyamines in food and their consequences for food quality and human health, Trends Food Sci. Technol. 6 (1995) 341-346.

[5] C. Ruiz-Capillas, A. Moral, Production of biogenic amines and their potential use as quality control indices for hake (Merluccius merluccius L.) stored in ice, J. Food Sci. 103 (2001) 1030-1032.

[6] S. Moret, D. Smela, T. Populin, L.S. Conte, A survey on free biogenic amine content of fresh and preserved vegetables, Food Chem. 89 (2005) 355-361.

[7] J. Stadnik, Z.J. Dolatowski, Biogenic amines in meat and fermented meat products, ACTA Sci. Polon. Technol. Alimen. 9 (2010) 251-263.

[8] S. Loret, P. Deloyer, G. Dandrifosse, Levels of biogenic amines as a measure of the quality of the beer fermentation process: Data from Belgian samples, Food Chem. 89 (2005) 519-525.

[9] R. Maijala, S. Eerola, S. Lievonen, P. Hill, T. Hirvi, Formation of biogenic amines during ripening of dry 
sausages as affected by starter culture and thawing time of raw materials, J. Food Sci. 60 (1995) 1187-1190.

[10] J. Karovicova, Z. Kohajdova, Biogenic amines in food, Chem. Papers 59 (2005) 70-79.

[11] F. Galgano, F. Favati, M. Bonadio, V. Lorusso, P. Romano, Role of biogenic amines as index of freshness in beef meat packed with different biopolymeric materials, Food Res. Int. 42 (2009) 1147-1152.

[12] B. Rivas, R. Gonzalez, J.M. Landete, R. Munoz, Characterization of a second ornithine decarboxylase isolated from Morganella morganii, J. Food Protect 71 (2008) 657-661.

[13] P. Kalac, P. Krausova, A review of dietary polyamines: Formation implications for growth and health and occurrence in foods, Food Chem. 90 (2005) 219-230.

[14] P. Kalac, M. Krizek, T. Pelikanova, M. Langova, O. Veskrna, Contents of polyamines in selected foods, Food Chem. 90 (2005) 561-564.

[15] M.H. Silla-Santos, Biogenic amines: Their importance in foods, Int. J. Food Microb. 29 (1996) 213-231.

[16] R.E. Anli, M. Bayram, Biogenic amines in wines, Food Rev. Int. 25 (2009) 86-102.

[17] FDA, Scombrotoxin (histamine) formation, in: Fish and Fisheries Products Hazards and Controls Guidance [Online], 2011, http://www,fda,gov/Food/GuidanceComplianceRegulator yInformation/GuidanceDocuments/Seafood/FishandFishe riesProductsHazardsandControlsGuide/default.htm.

[18] A. Naila, S. Flint, G. Fletcher, P. Bremer, G. Meerdink, Control of biogenic amines in food: Existing and emerging approaches, J. Food Sci. 75 (2010) 139-150.

[19] R. Maijala, S. Eerola, Contaminant lactic acid bacteria of dry sausages produce histamine and tyramine, Meat Sci. 35 (1993) 387-395.

[20] M.J.R. Nout, Fermented foods and food safety, Food Res. Int. 27 (1994) 291-298.

[21] H.S. Eerola, A.X. Roig-Sagues, T.K. Hirvi, Biogenic amines in Finnish dry sausages, J. Food Safety 18 (1998) 127-138.

[22] T. Hernandez-Jover, M. Izquierdo-Pulido, M.T. Veciana-Nogues, M.C. Vidal-Carou, Biogenic amine sources in cooked cured shoulder pork, J. Agric. Food Chem. 44 (1996) 3097-3101.

[23] A. Naila, S. Flint, G.C. Fletcher, P.J. Bremer, G. Meerdink, Biogenic amines and potential histamine forming bacteria in Rihaakuru (a cooked fish paste), Food Chem. 128 (2011) 479-484.

[24] I.A. Bulushi, S. Poole, H.C. Deeth, G.A. Dykes, Biogenic amines in fish: Roles in intoxication spoilage and nitrosamine formation: A review, C. Rev. Food Sci. Nutr. 49 (2009) 369-377.

[25] F. Wei, X. Xu, G. Zhou, C. Li, Y. Zhang, Irradiated
Chinese Rugao ham: Changes in volatile $N$-nitrosamine biogenic amine and residual nitrite during ripening and post-ripening, Meat Sci. 81 (2009) 451-455.

[26] M.L. Latorre-Moratalla, T. Veciana-Nogues, S. Bover-Cid, M. Garriga, T. Aymerich, E. Zanardi, et al., Biogenic amines in traditional fermented sausages produced in selected European countries, Food Chem. 107 (2008) 912-921.

[27] J.L. Mietz, E. Karmas, Chemical quality index of canned tuna as determined by high pressure liquid chromatography, J. Food Sci. 42 (1977) 155-158.

[28] C. Ruiz-Capillas, F. Jimenez-Colmenero, Biogenic amines in meat and meat products, C. Rev. Food Sci. Nutr. 44 (2004) 489-499.

[29] B. Wortberg, R. Woller, Quality and freshness of meat and meat products as related to their content of biogenic amines, Fleischwirts Chaft 62 (1982) 1457-1463.

[30] A. Halasz, A. Barath, L. Simon-Sarkadi, W. Holzapfel, Biogenic amines and their production by microorganisms in food, Trends Food Sci. Technol. 5 (1994) 42-49.

[31] R. Maijala, E. Nurmi, A. Fischer, Influence of processing temperature on the formation of biogenic amines in dry sausages, Meat Sci. 39 (1995) 9-22.

[32] F. Özogul, A. Polat, Y. Özogul, The effects of modified atmosphere packaging and vacuum packaging on chemical sensory and microbiological changes of sardines (Sardina pilchardus), Food Chem. 85 (2004) 49-57.

[33] M.H. Silla-Santos, in: R.M. Adams, M.J.R. Nout (Eds.), Fermentation and Food Safety, Maryland Aspen Publishers, 2001.

[34] H. Zhang, Z. Guo, F. Zhang, Q. Xu, X. Liang, HPLC for separation of coeluted flavonoids under RP-HPLC mode, J. Sep. Sci. 31 (2008) 1623-1627.

[35] S. Novella-Rodriguez, M.T. Veciana-Nogue, X.A. Roig-Sagues, A.X. Antonio, J.A.T. Trujillo-Mesa, M. Carmen, et al., Evaluation of biogenic amines and microbial counts throughout the ripening of goat cheeses from pasteurized and raw milk, J. Dairy Res. 71 (2004) 245-252.

[36] O. Pinho, A.I.E. Pintado, A.M.P. Gomes, M.M.E. Pintado, F.X. Malcata, I.M.P.L.V.O. Ferreira, Interrelationships among microbiological physicochemical and biochemical properties of Terincho cheese with emphasis on biogenic amines, J. Food Prot. 67 (2004) 2779-2785.

[37] G. Favaro, P. Pastore, G. Saccani, S. Cavalli, Determination of biogenic amines in fresh and processed meta by ion chromatography and integrated pulsed amperometric detection on Auelectrode, Food Chem. 105 (2007) 1652-1658.

[38] P. Kalac, J. Savel, M. Krizek, T. Petikanova, M. Prokopova, Biogenic amine formation in bottled beer, Food Chem. 79 (2002) 431-434. 
[39] G. Garai, I. Ibarbury, I. Berregi, O. Claisse, A. Lonvaud-Funel, A. Irastorza, et al., Glycerol metabolism a bitterness producing lactic acid bacteria in cidermaking, Int. J. Food Microb. 121 (2007) 253-261.

[40] K.M.K. Kebary, A.H. El-Sonbaty, R.M. Badawi, Effects of heating milk and accelerating ripening of low fat Rascheese on biogenic amines and free amino acids development, Food Chem. 64 (1999) 67-75.

[41] A.I.E. Pintadoa, O. Pinhob, I.M.P.L.V.O. Ferreirab, M.M.E. Pintado, A.M.P. Gomes, F.X. Malcataa, Microbiological biochemical and biogenic amine profiles of Terrincho cheese manufactured in several dairy farms, Int. Dairy J. 18 (2008) 631-640.

[42] M.L. Latorre-Moratalla, S. Bover-Cid, T. Aymerich, B. Marcos, M.C. Vidal-Carou, M. Garriga, Aminogenesis control in fermented sausages manufactured with pressurized meat batter and starter culture, Meat Sci. 75 (2007) 460-469.

[43] T. Komprda, D. Smela, P. Pechova, L. Kalhotka, J. Stencl, B. Klejdus, Effect of starter culture spice mix and storage time and temperature on biogenic amine content of dry fermented sausages, Meat Sci. 67 (2004) 607-616.

[44] H. Bozkurt, Utilization of natural antioxidants: Green tea extract and Thymbra spicata oil in Turkish dry fermented sausage, Meat Sci. 73 (2006) 442-450.

[45] H. Gençcelep, G. Kaban, M. Kaya, Effects of starter cultures and nitrite levels on formation of biogenic amines in sucuk, Meat Sci. 77 (2007) 424-430.

[46] F. Durlu-Özkaya, K. Ayhan, N. Vural, Biogenic amines produced by Enterobacteriaceae isolated from meat products, Meat Sci. 58 (2001) 163-166.

[47] Y. Nakada, Y. Itoh, Identification of the putrescine biosynthetic genes in Pseudomonas aeruginosa and characterization of agmatine deiminase and $\mathrm{N}$-carbamoylputrescine amidohydrolase of the arginine decarboxylase pathway, Microb. 149 (2003) 707-714.

[48] F. Masson, G. Johansson, M.C. Montel, Tyramine production by a strain of Carnobacterium divergens inoculated in meat fat mixture, Meat Sci. 52 (1999) 63-69.

[49] A.X. Roig-Sagues, M. Hernandez-Herrero, E.I. Lopez-Sabater, J.J. Rodriguez-Jerez, M.T. Mora-Ventura, Histidine decarboxylase activity of bacteria isolated from raw and ripened salchichon a Spanish cured sausage, J. Food Protec. 59 (1996) 516-520.

[50] H. Bozkurt, O. Erkmen, Effect of nitrate/nitrite on the quality sausage (sucuk) during ripening and storage, J. Sci. Food Agric. 84 (2004) 279-286.

[51] G. Suzzi, F. Gardini, Biogenic amines in dry fermented sausages: A review, Int. J. Food Microb. 88 (2003) 41-54.

[52] O.O. Lasekan, W.O. Lasekan, Biogenic amines in traditional alcoholic beverages produced in Nigeria, Food Chem. 69 (2000) 267-271.
[53] S. Yegin, A. Üren, Biogenic amine content of boza: A traditional cerealbased fermented Turkish beverage, Food Chem. 111 (2008) 983-987.

[54] S. Cortacero-Ramirez, D. Arraez-Roman, A. Segura-Carretero, A. Fernandez-Gutierrez, Determination of biogenic amines in beers and brewingprocess samples by capillary electrophoresis coupled to laser induced fluorescence detection, Food Chem. 100 (2007) 383-389.

[55] T. Tang, T. Shi, K. Qian, P. Li, J. Li, Y. Cao, Determination of biogenic amines in beer with precolumn derivatization by high performance liquid chromatography, J. Chromatog. 877 (2009) 507-512.

[56] M. Coton, A. Romano, G. Spano, K. Ziegler, C. Vetrana, C. Desmarais, et al., Occurrence of biogenic amineforming lactic acid bacteria in wine and cider, Food Microb. 27 (2010) 1078-1085.

[57] A.Y. Smit, M.D. Toit, Evaluating the influence of malolactic fermentation practices and ageing on lees on biogenic amine production in wine, Food Bioproc. Technol. 6 (2013) 198-206.

[58] V.D. Prete, A. Costantini, F. Cecchini, M. Morassut, E. Garcia-Moruno, Occurrence of biogenic amines in wine: The role of grapes, Food Chem. 112 (2009) 474-481.

[59] R.E. Anli, N. Vural, S. Yilmaz, Y.H. Vural, The determination of biogenic amines in Turkish red wines, $\mathrm{J}$. Food Comp. Analy. 17 (2004) 53-62.

[60] P. Hernadez-Orte, J.F. Cacho, V. Ferreira, Relationship between varietal amino acid profile of grapes and wine aromatic composition, experiments with model solutions and chemometric study, J. Agric. Food Chem. 50 (2002) 2891-2899.

[61] S. Millan, C. Sampedro, N. Unceta, A.M. Goicolea, J.R. Barrio, Simple and rapid determination of biogenic amines in wine by liquid chromatography-electrospray ionization ion trap mass spectrometry, Analytica Chimica Acta 584 (2007) 145-152.

[62] C. Proestos, P. Loukatos, M. Komaitis, Determination of biogenic amines in wines by HPLC with precolumn dansylation and fluorimetric detection, Food Chem. 106 (2008) 1218-1224.

[63] M.T. Veciana-Nogues, A. Marine-Font, M.C. Vidal-Carou, Biogenic amines as hygienic quality indicators of tuna, Relationships with microbial counts ATP related compounds volatile amines and organoleptic changes, J. Agric. Food Chem. 45 (1997) 2036-2041.

[64] M.B.A. Gloria, M. Izquierdo-Pulido, Levels and significance of biogenic amines in Brazilian beers, J. Food Comp. Anal. 12 (1999) 129-136.

[65] M. Izquierdo-Pulido, S. Albala-Hurtado, A. Marine-Font, M.C. Vidal-Carou, Biogenic amines in Spanis beers: Differences among breweries, Die Zeitschrift für Lebensm-Unter-und-Forschung 203 (1996) 507-511. 
[66] P. Kalac, M. Krizeck, A review of biogenic amines and polyamines in beer, J. Inst. Brewing 109 (2003) 123-128.

[67] S. Novella-Rodriguez, M.T. Veciana-Nogues, J. Saldo, M.C. Vidal-Carou, Effects of high hydrostatic pressure treatments on biogenic amine contents in goat cheeses during ripening, J. Agric. Food Chem. 50 (2002) 7288-7292.

[68] C. Ruiz-Capillas, F.J. Colmenero, A.V. Carrascosa, R. Munoz, Biogenic amine production in Spanish drycured "chorizo" sausage treated with high pressure and kept in chilled storage, Meat Sci. 77 (2007) 365-371.

[69] L. Simon-Sarkadi, K. Pasztor-Huszar, I. Dalmadi, G. Kisko, Effect of high hydrostatic pressure processing on biogenic amine content of sausage during storage, Food Res. Int. 47 (2012) 380-384.

[70] Ç. Soysal, Z. Söylemez, F. Bozoğlu, Effect of high hydrostatic pressure and temperature on carrot peroxidase inactivation, Eur. Food Res. Technol. 218 (2004) 152-156.

[71] E. Penas, J. Frias, B. Sidro, C. Vidal-Valverde, Impact of fermentation conditions and refrigerated storage on microbial quality and biogenic amine content of sauerkraut, Food Chem. 123 (2010) 143-150.

[72] M.F. Patterson, A review: Microbiology of pressure treated foods, J. App. Microb. 98 (2005) 1400-1409.

[73] R. Lanciotti, F. Patrignani, L. Iucci, M.E. Guerzoni, G. Suzzi, N. Belletti, et al., Effects of milk high pressure homogenization on biogenic amine accumulation during ripening of ovine and bovine Italian cheeses, Food Chem. 104 (2007) 693-701.

[74] T. Radomyski, E.A. Murano, D.G. Olson, P.S. Murano, Elimination of pathogens of significance in food by low dose irradiation: A review, J. Food Prot. 57 (1994) 73-80.

[75] J.H. Kim, H.J. Ahn, D.H. Kim, C. Jo, H.S. Yook, M.W. Byun, Irradiation effects on biogenic amines in Korean fermented soybean paste during fermentation, J. Food Sci. 68 (2003) 80-84.

[76] J.H. Kim, H.J. Ahn, C. Jo, H.J. Park, Y.J. Chung, M.W. Byun, Radiolysis of biogenic amines in model system by gamma irradiation, Food Cont. 15 (2004) 405-408.

[77] J.S. Min, S.O. Lee, A. Jang, C. Jo, M. Lee, Irradiation and organic acid treatment for microbial control and the production of biogenic amines in beef and pork, Food Chem. 104 (2007) 791-799.

[78] H.J. Ahn, H.S. Yook, M.S. Rhee, C.H. Lee, Y.J. Cho, M.W. Byun, Application of gamma irradiation on breakdown of hazardous volatile N-nitrosamines, J. Food Sci. 67 (2002) 586-599.

[79] L.J. Frewer, K. Bergmannc, M. Brennana, R. Liond, R. Meertens, G. Rowea, et al., Consumer response to novel agrifood technologies: Implications for predicting consumer acceptance of emerging food technologies, Trends Food Sci. Technol. 22 (2011) 442-456.
[80] J.H. Kim, H.J. Ahn, J.W. Lee, H.J. Park, G.H. Ryu, I.J. Kang, et al., Effects of gamma irradiation on the biogenic amines in pepperoni with different packaging conditions, Food Chem. 89 (2005) 199-205.

[81] J.H. Kim, D.H. Kim, H.J. Ahn, H.J. Park, M.W. Byun, Reduction of the biogenic amine contents in low saltfermented soybean paste by gamma irradiation, Food Cont. 16 (2005) 43-49.

[82] M.A. Rabie, H.I. Siliha, M. ElSaidy, A.A. ElBadawy, F.X. Malcata, Effect of gammair radiation upon biogenic amine formation in blue cheese during storage, Int. Dairy J. 21 (2011) 373-376.

[83] R. Mbarki, N.B. Miloud, S. Semli, S. Dhib, S. Sadok, Effect of vacuum packaging and low dose irradiation on the microbial chemical and sensory characteristics of chub mackerel (Scomber japonicus), Food Microb. 26 (2009) 821-826.

[84] Ü. Yücel, A. Üren, Biogenic amines in Turkish type pickled cabbage: Effects of salt and citric acid concentration, Acta Alimeteria 37 (2008) 115-122.

[85] S. Kurt, O. Zorba, The effects of ripening period nitrite level and heat treatment on biogenic amine formation of "sucuk"-A Turkish dry fermented sausage, Meat Sci. 82 (2009) 179-184.

[86] H. Bozkurt, O. Erkmen, Effects of temperature humidity and additives on the formation of biogenic amines in sucuk during ripening and storage periods, Food Sci. Technol. Int. 10 (2004) 21-28.

[87] S. Bover-Cid, J.M. Miguelez-Arrizado, M.C. Vidal-Carou, Biogenic amine accumulation in ripened sausages affected by the addition of sodium sulphite, Meat Sci. 59 (2001) 391-396.

[88] S. Bover-Cid, M. Izquierdo-Pulido, M.C. Vidal-Carou, Changes in biogenic amine and polyamine contents in slightly fermented sausages manufactured with and without sugar, Meat Sci. 57 (2001) 215-221.

[89] H. Bozkurt, Comparison of the effects of sesame and Thymbra spicata oil during the manufacturing of Turkish dry fermented sausage, Food Cont. 18 (2007) 149-156.

[90] S. Karabacak, H. Bozkurt, Effects of Urtica dioica and Hibiscus sabdariffa on the quality and safety of sucuk (Turkish dry fermented sausage), Meat Sci. 78 (2008) 288-296.

[91] J.H. Mah, Y.J. Kim, H.J. Hwang, Inhibitory effects of garlic and other spices on biogenic amine production in Myeolchijeot Korean salted and fermented anchovy product, Food Cont. 20 (2009) 449-454.

[92] J.H. Mah, H.J. Hwang, Effects of food additives on biogenic amine formation in Myeolchijeot a salted and fermented anchovy (Engraulis japonicus), Food Chem. 114 (2009) 168-173.

[93] M. Yamada, T. Watanabe, S. Harino, H. Fukui, H. Wada, 
The effects of protease inhibitors on histidine decarboxylase activities and assay of enzyme in various rat tissues, BBA Enzymol. 615 (1980) 458-459, 462-463.

[94] F.E. Romantsev, V.N. Prozorovskii, Proteolytic resistance and thermostability of catalase and histidine decarboxylase from Micrococcus sp., Biulleten Eksperimentalnoi Biologii I Meditsiny. 97 (1984) 414-415.

[95] K. Ayhan, N. Kolsarici, G.A. Özkan, The effects of a starter culture on the formation of biogenic amines in Turkish soudjoucks, Int. J. Food Microb. 53 (1999) 183-188.

[96] J.H. Mah, H.J. Hwang, Inhibition of biogenic amine formation in a salted and fermented anchovy by Staphylococcus xylosus as a protective culture, Food Cont. 20 (2009) 796-801.

[97] P. Kalac, J. Spicka, M. Krizek, T. Pelikanova, The effect of lactic acid bacteria inoculants on biogenic amines formation in sauerkraut, Food Chem. 70 (2000) 355-359.

[98] A. Tosukhowong, W. Visessanguan, L. Pumpuang, P. Tepkasikul, A. Panya, R. Valyasevi, Biogenic amine formation in Nham a Thai fermented sausage and the reduction by commercial starter culture Lactobacillus plantarum BCC 9546, Food Chem. 129 (2011) 846-853.

[99] C. Gonzalez-Fernandez, E.M. Santos, I. Jaime, J. Rovira, Influence of starter cultures and sugar concentrations on biogenic amine contents in chorizo dry sausage, Food Microb. 20 (2003) 275-284.

[100] V. Capozzi, P. Russo, V. Ladero, M. Fernández, D. Fiocco, M.A. Alvarez, et al., Biogenic amines degradation by Lactobacillus plantarum: Toward a potential application in wine, Frontier Microb. 3 (2012) 122.

[101] C. Cueva, A. García-Ruiz, E. González-Rompinelli, B. Bartolome, P.J. Martín-Álvarez, O. Salazar, et al., Degradation of biogenic amines by vineyard ecosystem, potential use in winemaking, J. App. Microb. 112 (2012) 672-682.

[102] A. Naila, S. Flint, G.C. Fletcher, B.J. Bremer, G. Meerdink, R.H. Morton, Prediction of the amount and rate of histamine degradation by diamine oxidase (DAO), Food Chem. 135 (2012) 2650-2660.

[103] M.L.N.E. Dapkevicius, M.J.R. Nout, F.M. Rombouts, Biogenic amine formation and degradation by potential fish silage starter microorganisms, Int. Food Microb. 57 (2000) 107-114.

[104] L.E. Jeremiah, Packaging alternatives to deliver fresh meats using short or longterm distribution, Food Res. Int.
34 (2001) 749-772.

[105] J. Emborg, B.G. Laursen, P. Dalgaard, Significant histamine formation in tuna (Thunnus albacares) at $2{ }^{\circ} \mathrm{C}$-Effect of vacuum and modified atmosphere packaging on psychrotolerant bacteria, Int. J. Food Microb. 101 (2005) 263-279.

[106] A. Patsias, I. Chouliara, E.K. Paleologos, I. Savvaidis, M.G. Kontominas, Relation of biogenic amines to microbial and sensory changes of precooked chicken meat stored aerobically and under modified atmosphere packaging at $4{ }^{\circ} \mathrm{C}$, Eur. Food Res. Techn. 223 (2006) 683-689.

[107] V.K. Singh, S. Sanjay, S. Sushma, D.K. Singh, Effect of active molluscicidal component of spices on different enzyme activities and biogenic amine levels in the nervous tissue of Lymnaea acuminate, Phytotherapy Res. 13 (1999) 649-654.

[108] P. Dalgaard, H.L. Madsen, N. Samieian, J. Emborg, Biogenic amine formation and microbial spoilage in chilled garfish (belone) effect of modified atmosphere packaging and previous frozen storage, J. App. Microb. 101 (2006) 80-95.

[109] G. Duflos, Histamine risk in fishery products, Bulletin de l'Academie Veterinaire de France 162 (2009) 241-246.

[110] W.X. Du, C.M. Lin, A.T. Phu, J.A. Cornell, M.R. Marshall, C.I. Wei, Development of biogenic amines in yellowfin tuna (Thunnus albacares): Effect of storage and correlation with decarboxylase positive bacterial flora, J. Food Sci. 67 (2002) 292-301.

[111] M. Fernandez, D.M. Linares, B. Del Rio, V. Ladero, M.A. Alvarez, HPLC quantification of biogenic amines in cheese: Correlation with PCR detection of tyramine producing microorganisms, J. Dairy Res. 74 (2007) 276-282.

[112] D.M. Linares, M.C. Martin, V. Ladero, M.A. Alvarez, M. Fernandez, Biogenic amines in dairy products, C. Rev. Food Sci. Nutr. 51 (2011) 691-703.

[113] J. Emborg, P. Dalgaard, Formation of histamine and biogenic amines in colds moked tuna: An investigation of psychrotolerant bacteria from samples implicated in cases of histamine fish poisoning, J. Food Prot. 69 (2006) 897-906.

[114] S. Bover-Cid, M.J. Miguelez-Arrizado, L.L.L. Moratalla, M.C.V. Vidal-Carou, Freezing of meat raw materials affects tyramine and diamine accumulation in spontaneously fermented sausages, Meat Sci. 72 (2006) 62-68. 